\section{Effect of phosphorylation on the interaction of calcium with leucine-rich amelogenin peptide}

Le Norcy E, Kwak S-Y, Allaire M, Fratzl P, Yamakoshi Y, Simmer JP, Margolis HC. Effect of phosphorylation on the interaction of calcium with leucine-rich amelogenin peptide.

Eur J Oral Sci 2011; 119 (Suppl. 1): 97-102. (C) 2011 Eur J Oral Sci

Amelogenin undergoes self-assembly and plays an essential role in guiding ename mineral formation. The leucine-rich amelogenin peptide (LRAP) is an alternative splice product of the amelogenin gene and is composed of the $\mathrm{N}$ terminus (containing the only phosphate group) and the $\mathrm{C}$ terminus of full-length amelogenin. This study was conducted to investigate further the role of phosphorylation in LRAP selfassembly in the presence and absence of calcium using small angle X-ray scattering (SAXS). Consistent with our previous dynamic light-scattering findings for phosphorylated $(+\mathrm{P})$ and non-phosphorylated $(-\mathrm{P})$ LRAP, SAXS analyses revealed radii of gyration $\left(R_{g}\right)$ for $\operatorname{LRAP}(-\mathrm{P})(46.3-48.0 \AA)$ that were larger than those for $\operatorname{LRAP}(+\mathrm{P})(25.0-27.4 \AA$ ) at $\mathrm{pH}$ 7.4. However, added calcium (up to $2.5 \mathrm{mM}$ ) induced significant increases in the $R_{g}$ of $\operatorname{LRAP}(+\mathrm{P})$ (up to $46.4 \AA$ ), while it had relatively little effect on LRAP(-P) particle size. Furthermore, SAXS analyses suggested compact folded structures for $\operatorname{LRAP}(-\mathrm{P})$ in the presence and absence of calcium, whereas the conformation of $\operatorname{LRAP}(+\mathrm{P})$ changed from an unfolded structure to a more compact structure upon the addition of calcium. We conclude that the single phosphate group in LRAP $(+\mathrm{P})$ induces functionally important conformational changes, suggesting that phosphorylation may also influence amelogenin conformation and protein-mineral interactions during the early stages of amelogenesis.

\section{Elvire Le Norcy ${ }^{1,2}$, Seo-Young Kwak $^{1,2}$, Marc Allaire ${ }^{3}$, Peter Fratzl ${ }^{4}$, Yasuo Yamakoshi ${ }^{5}$, James $P$. Simmer ${ }^{5}$, Henry C. Margolis ${ }^{1,2}$}

${ }^{1}$ Department of Biomineralization, The Forsyth Institute, Cambridge, MA, USA; ${ }^{2}$ Department of Developmental Biology, Harvard School of Dental Medicine, Boston, MA, USA; ${ }^{3}$ National Synchrotron Light Source, Brookhaven National Laboratory, Upton, NY, USA; ${ }^{4}$ Department of Biomaterials, Max Planck Institute of Colloids and Interfaces, Research Campus Golm, Potsdam, Germany;

${ }^{5}$ Department of Biologic and Materials Sciences, University of Michigan School of Dentistry, Ann Arbor, MI, USA

\section{Henry C. Margolis, Department of} Biomineralization, The Forsyth Institute, 245 First Street, Cambridge, MA 02142, USA

\section{Telefax: +1-617-8928432}

E-mail hmargolis@forsyth.org

Key words: amelogenin; conformation; leucinerich amelogenin peptide; phosphorylation; small angle X-ray scattering

Accepted for publication September 2011
Enamel is the most highly mineralized vertebrate tissue, composed of $\sim 96 \%$ mineral and $4 \%$ organic material and water. During amelogenesis, the ameloblast secretes matrix proteins and is responsible for creating and maintaining an extracellular environment favorable for mineral deposition (1). Amelogenin, the predominant enamel matrix protein, has been shown to undergo selfassembly to form spherical or oblate-shaped nanoparticles (2-4), as well as elongated structures (5-7), and is believed to play an essential role in guiding the formation of ordered arrays of apatitic crystals during enamel development $(5,8-12)$. In particular, both the N-terminal domain (containing the only phosphate group on serine 16) and the hydrophilic C-terminal domain of full-length amelogenin (Fig. 1) have been shown to be critical for proper enamel formation (13-16). It is also believed that during enamel mineral growth, the concentration of free calcium ions is regulated, in part, by the binding of calcium to enamel proteins and their proteolytic cleavage products $(17,18)$

The leucine-rich amelogenin peptide (LRAP), a 56amino-acid alternative splice product of the amelogenin gene found throughout amelogenesis and composed of the first $33 \mathrm{~N}$-terminal and the last $23 \mathrm{C}$-terminal amino acids of full-length amelogenin (Fig. 1), has recently been shown by us to share similar behavioral properties with amelogenin with respect to self-assembly and its ability to regulate crystal growth in vitro $(19,20)$. As in solution (19), LRAP has also been shown to assemble into nanospheres on fluoroapatite (21) and on surfactant-coated gold surfaces (22). Furthermore, it has been shown (23) that non-phosphorylated LRAP $[\operatorname{LRAP}(-\mathrm{P})]$ and recombinant full-length human amelogenin ( $\mathrm{rH} 174)$ have the same capacity to bind calcium (i.e. four to six calcium ions per molecule), although the calcium affinity constant for LRAP was greater than that for the full-length amelogenin. Based on similarities of structure and behavior, LRAP has allowed us to investigate the potential role of specific amino-acid domains of amelogenin and phosphorylation in protein self-assembly using dynamic light scattering (DLS) and transmission electron microscopy (TEM). Such studies have illustrated potentially important differences in the self-assembly behavior of phosphorylated LRAP $[(\operatorname{LRAP}(+\mathrm{P})]$ and $\operatorname{LRAP}(-\mathrm{P})$ (19).

The aim of the present study was to extend these recent findings using small angle X-ray scattering (SAXS), to investigate further the role of phosphorylation in LRAP self-assembly, in the presence and absence of calcium, through comparative studies of $\operatorname{LRAP}(+\mathrm{P})$ and $\operatorname{LRAP}(-\mathrm{P})$ forms of LRAP (Fig. 1). 


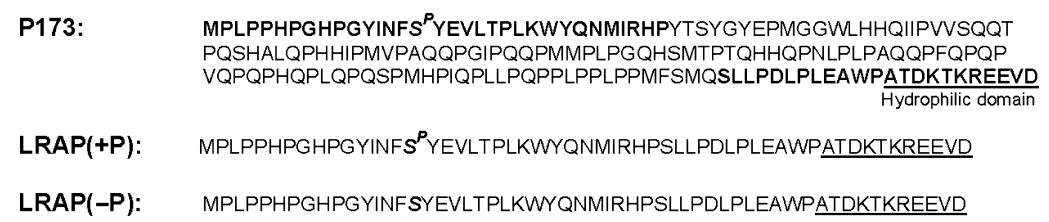

Fig. 1. Amino-acid sequences of the full-length porcine amelogenin (P173) and the phosphorylated (+P) and non-phosphorylated (-P) leucine-rich amelogenin peptide (LRAP). Note that LRAP is composed exclusively of the N-and C-terminal domains (shown in bold type) of the full-length molecule.

\section{Material and methods \\ Preparation of amelogenin peptides}

$\operatorname{LRAP}(+\mathrm{P})$ and $\operatorname{LRAP}(-\mathrm{P})$ forms of porcine LRAP $(56$ amino acids) were synthesized commercially (NEO Peptide, Cambridge, MA, USA) and purified as previously described (24). Lyophilized peptides were weighed and dissolved in distilled deionized water at room temperature to yield stock solutions of $5-6 \mathrm{mg} \mathrm{ml}^{-1}$ of peptide. The solutions were kept at room temperature for $30 \mathrm{~min}$ and then stored at $4^{\circ} \mathrm{C}$ for $24 \mathrm{~h}$ before checking complete dissolution by DLS. Peptide stock solutions were centrifuged $\left(10,900 \times g, 4^{\circ} \mathrm{C}\right.$, $20 \mathrm{~min}$ ) just before use.

\section{SAXS measurements}

Aliquots of peptides were adjusted to a $\mathrm{pH}$ of $\sim 7.4$ with small amounts of $\mathrm{KOH}$ and $\mathrm{HCl}$ to obtain final concentrations of $2 \mathrm{mg} \mathrm{ml}^{-1}(0.31 \mathrm{mM})$ and $5 \mathrm{mg} \mathrm{ml}^{-1}(0.76 \mathrm{mM})$ of LRAP (total volume $70 \mu \mathrm{l}$ ). In selected experiments, calcium chloride was added to peptide solutions before adjustment of $\mathrm{pH}$ to yield final concentrations of $0.76-2.5 \mathrm{mM}$ calcium (total volume $=70 \mu \mathrm{l}$ ). Hence, on a molar basis, the calcium to protein ratios ranged from 1.0 to 8.1 . All sample preparations were carried out at room temperature.

Solution X-ray scattering experiments were carried out at the National Synchrotron Light Source at Brookhaven National Laboratory, on beamline X9 (25). The X-ray wavelength was $0.918 \AA$ and the sample-detector distance was $3.4 \mathrm{~m}$. The sample holder was a 0.9 -mm-diameter quartz capillary tube that was open at both ends to allow continuous flow of the sample to avoid X-ray damage. Each measurement required $15 \mu \mathrm{l}$ of sample and an exposure time of $30 \mathrm{~s}$ at $13^{\circ} \mathrm{C}$. Triplicate measurements were conducted for each experiment. The two-dimensional images acquired on a PILATUS $300 \mathrm{~K}$ detector (Dectris, Baden, Switzerland) were averaged into one-dimensional scattering curves and then water scattering was subtracted using the pyXS software developed at the beamline. Solution X-ray scattering data were further analyzed using Primus software (26). The data consisted of the scattering vector, $s$ [defined as $s=2 \pi$ / $d$ or $4 \pi \sin (\theta) / \lambda]$, and the corresponding intensity, $I(s)$. As noted in the Results section, Guinier and Kratky plots were used to analyze the data. Guinier analyses consisted of the plotting of $\log I$ vs. $s^{2}$ at very low $s$ values and were used to determine the radius of gyration, $R_{\mathrm{g}}$, and the extrapolated intensity at the zero scattering angle, $I_{\mathrm{o}}$, with $R_{\mathrm{g}}$ being the mass distribution of the macromolecule around its center of gravity (27). Kratky analyses were carried out by plotting $I(s) \times s^{2}$ vs. $s$ and provided information on peptide folding, as described later (28). The number of molecules per particle was estimated using the following formula: $N=$ $\left(V_{\mathrm{S}} \times N_{\mathrm{A}} \times \delta_{\mathrm{p}}\right) / F_{\mathrm{W}}$; where, $V_{\mathrm{S}}=\left(4 \pi R_{\mathrm{g}}{ }^{3}\right) / 3$, the density of the protein $\delta_{\mathrm{p}}=1.44 \mathrm{~g} \mathrm{~cm}^{-3}$ (3), $N_{\mathrm{A}}$ is the Avogadro constant, and $F_{\mathrm{W}}=6537.52 \mathrm{Da}$.

\section{Results \\ Size of particles formed}

Small angle X-ray scattering enables determination of the molecular size, shape, and conformational change of a protein molecule in solution. As shown in Fig. 2, the scattering generally exhibited fairly good linear dependence $\left[\log I(s)\right.$ vs. $\left.s^{2}\right]$ at low $s$, indicating little to no bulk aggregation and allowing further data processing. As shown in Table 1, Guinier plots revealed that the $R_{\mathrm{g}}$ was $48.0 \pm 0.05 \AA$ for $\operatorname{LRAP}(-\mathrm{P})$ but only $25.0 \pm 0.50 \AA$ for $\operatorname{LRAP}(+\mathrm{P})$ (both at $\left.2 \mathrm{mg} \mathrm{ml}^{-1}, 13^{\circ} \mathrm{C}, \mathrm{pH} 7.4\right)$, in the absence of added calcium. The $R_{\mathrm{g}}$ values for each peptide were very similar when the peptide concentration was increased to $5 \mathrm{mg} \mathrm{ml}^{-1}$, with an $R_{\mathrm{g}}$ of $46.3 \pm 0.02 \AA$ for $\operatorname{LRAP}(-\mathrm{P})$ and an $R_{\mathrm{g}}$ of $27.4 \pm 0.08 \AA$ for $\operatorname{LRAP}(+\mathrm{P})$, under the same experimental conditions. The addition of $2.5 \mathrm{mM}$ calcium to $2 \mathrm{mg} \mathrm{ml}^{-1}$ solutions of peptide, however, induced a significant increase in the $R_{\mathrm{g}}$ for $\operatorname{LRAP}(+\mathrm{P})$ to $43.9 \pm 0.05 \AA$, but it had relatively little effect on the $R_{\mathrm{g}}$ of $\operatorname{LRAP}(-\mathrm{P})$, with a value of

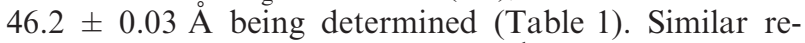
sults were obtained for $5 \mathrm{mg} \mathrm{ml}^{-1}$ peptide solutions containing $2.5 \mathrm{mM}$ calcium, yielding $R_{\mathrm{g}}$ values for $\operatorname{LRAP}(+\mathrm{P})$ and $\operatorname{LRAP}(-\mathrm{P})$ of $46.4 \pm 0.06 \AA$ and $53.9 \pm 0.06 \AA$ A, respectively. As also shown in Table 1 , using peptide concentrations of $5 \mathrm{mg} \mathrm{ml}^{-1}$, increasing concentrations of calcium added to $\operatorname{LRAP}(-\mathrm{P})$ solutions resulted in a progressive, but slight, increase in the $R_{\mathrm{g}}$ values, whereas increased calcium concentrations resulted in marked concentration-dependent increases in the $R_{\mathrm{g}}$ values for $\operatorname{LRAP}(+\mathrm{P})$.

Increased $I_{\mathrm{O}}$ values per unit peptide concentration (c), $I_{\mathrm{o}} / \mathrm{c}$ (Table 1$)$, calculated for the $\operatorname{LRAP}(+\mathrm{P})$ samples, however, were consistent with peptide self-assembly (29), as particle sizes $\left(R_{\mathrm{g}}\right)$ increased by an overall factor of around two upon the addition of higher concentrations of calcium. In contrast, as clearly seen in $5 \mathrm{mg} \mathrm{ml}^{-1}$ samples, a much smaller increase in $I_{\mathrm{o}} / \mathrm{c}$ was observed for LRAP(-P) upon the addition of calcium. Similar increases in the number of molecules per particle were also observed (Table 1). Overall, under comparable conditions, $I_{\mathrm{O}}$ values were larger for $\operatorname{LRAP}(-\mathrm{P})$ than for $\operatorname{LRAP}(+\mathrm{P})$ and corresponded to a somewhat greater number of molecules per particle.

\section{Determination of conformational changes}

Kratky plots $\left[I(s) \times s^{2}\right.$ vs. $\left.s\right]$ of SAXS data present characteristic and distinctly different shapes for globular fol- 

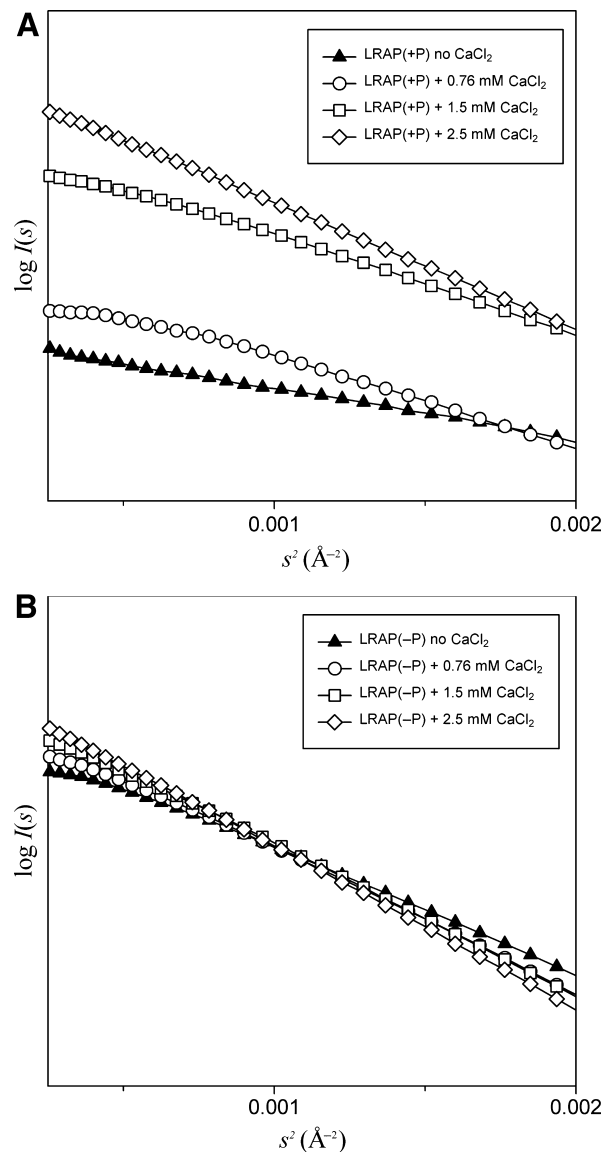

Fig. 2. The Guinier region of the scattering curve for phosphorylated leucine-rich amelogenin peptide $[\operatorname{LRAP}(+\mathrm{P})](\mathrm{A})$ and non-phosphorylated leucine-rich amelogenin peptide $[\operatorname{LRAP}(-\mathrm{P})](\mathrm{B})$ data recorded in the absence and in the presence of $0.76-2.5 \mathrm{mM}$ calcium chloride $\left(\mathrm{CaCl}_{2}\right)$. Curves in (A) and (B) exhibit fairly good linear dependence of $\log I(s)$ vs. $s^{2}$, indicating little to no bulk aggregation. Data shown are for $5 \mathrm{mg} \mathrm{ml}^{-1}$ peptide concentrations. $I(s)$, intensity of $s ; s$, scattering vector.

ded molecules and extended-chain or random-coil molecules of similar molecular mass (30-32). Globular macromolecules follow Porod's law and have bell-shaped curves as the clearly defined surface of the protein leads to a drop in intensity with the fourth power of $s(31)$, whereas extended molecules, such as unfolded peptides, lack this peak and have a plateau or increase slightly in the larger $s$ range. As shown in Fig. 3A,B,D, the Kratky plot of LRAP $(-P)$ data in the absence of calcium showed a bellshaped curve, indicating a globular structure. The addition of up to $2.5 \mathrm{mM}$ calcium did not induce an apparent conformational change, as $\operatorname{LRAP}(-\mathrm{P})$ exhibited similar bell-shaped curves in the presence of various concentrations of calcium $(0.76-2.5 \mathrm{mM})$, as it did in its absence (Fig. 3A,B,D). On the contrary, in the absence of calcium, $\operatorname{LRAP}(+\mathrm{P})$ showed a plateau indicating an unfolded extended random structure (Fig. 3A-C). However, a prominent peak appeared upon the addition of $2.5 \mathrm{mM}$ calcium, suggesting the formation of a more globular $\operatorname{LRAP}(+\mathrm{P})-\mathrm{Ca}$ structure (Fig. 3A,B). The extent of folding of the $\operatorname{LRAP}(+\mathrm{P})$ peptide was also found to be dependent upon the concentration of calcium added (Fig. 3C). The addition of $0.76 \mathrm{mM}$ calcium induced the formation of a very slight peak, suggesting that the peptide remained mostly in the unfolded state with the appearance of some globular features; upon the addition of $1.5 \mathrm{mM}$ calcium the peak appeared more pronounced, indicating an increase in peptide folding. With the addition of $2.5 \mathrm{mM}$ calcium, the peak of the Kratky plot for $\operatorname{LRAP}(+\mathrm{P})$ became even more pronounced and began to resemble that of the non-phosphorylated $\operatorname{LRAP}(-\mathrm{P})$ peptide, although the curves remained somewhat distinct at higher values of $s$ (Fig. 3A-D).

\section{Discussion}

Leucine-rich amelogenin peptide, like amelogenin, is a phosphorylated protein that is secreted with a single phosphate group on serine 16 (33). Previous studies from our laboratory have shown that this single phosphate group has a major influence on the properties of amelogenin. In particular, in comparison with their nonphosphorylated (recombinant or synthetic) counterparts, phosphorylated (native and synthetic) forms of fulllength porcine amelogenin (P173) (7), truncated porcine amelogenin P148 (8), full-length $\operatorname{LRAP}(+\mathrm{P})(19)$, and a truncated form of LRAP $[\operatorname{LRAP}(+\mathrm{P},-\mathrm{CT}](20)$ all exhibit the capacity to stabilize amorphous calcium phosphate (ACP) effectively [i.e. prevent its transformation to crystalline hydroxyapatite (HA)], under experimental conditions designed to support the spontaneous formation of calcium phosphates in vitro. In sharp contrast to these findings, non-phosphorylated forms of fulllength amelogenin and full-length LRAP were shown to guide the formation of ordered bundles of apatitic crystals $(5,8,19)$. This latter behavior has been attributed to the ability of full-length amelogenin $(6,7,15,34)$ and LRAP (19) to form higher-order chain-like structures under specified conditions of $\mathrm{pH}$. The presence of calcium has also previously been shown to enhance the formation of chain-like structures of recombinant full-length mouse rM179 (5) and human rH174 (35), amelogenin, and LRAP (19). Notably, as shown in the latter study, particle sizes and the formation of chain-like structures were enhanced to a greater degree for the phosphorylated form of LRAP. This conclusion was based on DLS and TEM observations. Our present SAXS findings support this conclusion and further demonstrate that the presence of calcium has a profound effect on the size and conformation of $\operatorname{LRAP}(+\mathrm{P})$ and little effect on those characteristics of $\operatorname{LRAP}(-\mathrm{P})$. This effect is caused by the presence of a single phosphate group on serine 16 .

Guinier (Table 1) and Kratky (Fig. 3) analyses revealed further assembly and enhanced folding of $\operatorname{LRAP}(+\mathrm{P})$ upon the addition of calcium (Fig. 3A-C). Further assembly with added calcium is indicated (Table 1 ) by marked increases in $R_{\mathrm{g}}$ values, in estimates of the number of molecules per particle, and in $I_{\mathrm{o}} / \mathrm{c}$ values. However, it should be noted that $I_{\mathrm{o}}$ values are affected by factors other than particle size (i.e. $R_{\mathrm{g}}$ ), such as particle shape and particle density, in the proportion 
Table 1

Guinier analyses of effect of peptide and calcium concentrations on particle size

\begin{tabular}{|c|c|c|c|c|c|c|}
\hline \multirow{2}{*}{$\begin{array}{l}\text { Peptide } \\
\text { concentration }\end{array}$} & \multirow[b]{2}{*}[\mathrm{CaCl}_{2}]{$(\mathrm{mM})$} & \multicolumn{4}{|c|}{ Guinier } & \multirow{2}{*}{$\begin{array}{l}\text { Number of molecules } \\
\text { per particle }\end{array}$} \\
\hline & & $R_{\mathrm{g}}(\AA)$ & Error & $I_{\mathrm{O}}$ & $I_{\mathrm{o}} / \mathrm{c}$ & \\
\hline \multicolumn{7}{|l|}{$2 \mathrm{mg} \mathrm{ml}^{-1}$} \\
\hline \multirow[t]{2}{*}{$\operatorname{LRAP}(+\mathrm{P})$} & 0 & 25.0 & 0.489 & 8.39 & 4.2 & 9 \\
\hline & 2.5 & 43.9 & $5.34 \mathrm{E}-02$ & 73.12 & 36.6 & 47 \\
\hline \multirow[t]{2}{*}{ LRAP(-P) } & 0 & 48.0 & $5.34 \mathrm{E}-02$ & 100.33 & 50.2 & 61 \\
\hline & 2.5 & 46.2 & $2.59 \mathrm{E}-02$ & 85.87 & 42.9 & 55 \\
\hline \multicolumn{7}{|l|}{$5 \mathrm{mg} \mathrm{ml}^{-1}$} \\
\hline \multirow[t]{4}{*}{$\operatorname{LRAP}(+\mathrm{P})$} & 0 & 27.4 & $7.77 \mathrm{E}-02$ & 20.304 & 4.06 & 11 \\
\hline & 0.76 & 35.5 & $5.32 \mathrm{E}-02$ & 51.829 & 10.4 & 25 \\
\hline & 1.5 & 40.7 & $4.08 \mathrm{E}-02$ & 115.14 & 23.0 & 37 \\
\hline & 2.5 & 46.4 & $6.41 \mathrm{E}-02$ & 165.03 & 33.0 & 56 \\
\hline \multirow[t]{4}{*}{ LRAP(-P) } & 0 & 46.3 & $2.20 \mathrm{E}-02$ & 230.17 & 46.0 & 55 \\
\hline & 0.76 & 49.5 & $2.80 \mathrm{E}-02$ & 254.58 & 50.9 & 67 \\
\hline & 1.5 & 52.0 & 4.30E-02 & 286.57 & 57.3 & 78 \\
\hline & 2.5 & 53.9 & $6.24 \mathrm{E}-02$ & 302.99 & 60.6 & 87 \\
\hline
\end{tabular}

LRAP $(-\mathrm{P})$ and LRAP $(+\mathrm{P})$ exhibit similar radii of gyration $\left(R_{\mathrm{g}}\right)$ at 2 and $5 \mathrm{mg} \mathrm{ml}^{-1}$. The $R_{\mathrm{g}}$ of $\mathrm{LRAP}(+\mathrm{P})$ is half that of LRAP $(-\mathrm{P})$ in the absence of calcium at $\mathrm{pH} \sim 7.4 . R_{\mathrm{g}}$ and $I_{\mathrm{o}} / \mathrm{c}$ for $\operatorname{LRAP}(-\mathrm{P})$ increased slightly upon the addition of up to $2.5 \mathrm{mM}$ calcium, whereas marked and progressive increases in these parameters were observed in the presence of $\operatorname{LAP}(+\mathrm{P})$, upon the addition of calcium. The estimated number of molecules calculated from the $R_{\mathrm{g}}$ is presented for comparison purposes.

$I_{\mathrm{o}}$, the extrapolated intensity at zero scattering angle; $I_{o} / c$, the $I_{\mathrm{O}}$ value per unit peptide concentration; LRAP, leucine-rich amelogenin peptide; LRAP $(-\mathrm{P})$, non-phosphorylated leucine-rich amelogenin peptide; LRAP $(+\mathrm{P})$, phosphorylated leucine-rich amelogenin peptide.

$I_{\mathrm{o}} / \mathrm{c} \propto\left(\rho_{\text {particle }}-\rho_{\text {solvent }}\right)^{2} \times V_{\text {particle, }}$ where $\rho$ indicates (electron) density and $V_{\text {particle }}$ indicates the volume of a single particle (27). Although our present analyses do not take potential differences in these latter factors into consideration, $\operatorname{LRAP}(+\mathrm{P})$ and $\operatorname{LRAP}(-\mathrm{P})$ were found to behave quite differently in the absence and presence of calcium, particularly with respect to folding. In contrast to that seen with $\operatorname{LRAP}(+\mathrm{P})$, as observed previously using circular dichroism (36), LRAP(-P) does not undergo significant conformational change upon the addition of calcium (Fig. 3A,B,D). Moreover, as demonstrated here (Fig. 3), $\operatorname{LRAP}(+\mathrm{P})$ exhibits a more unfolded structure than $\operatorname{LRAP}(-\mathrm{P})$, particularly in the absence and presence of lower concentrations of calcium. It appears that in the presence of calcium, unfolded LRAP $(+\mathrm{P})$ molecules assemble to form more globularlike structures and the process is primarily triggered by calcium concentration (Table 1 and Fig. 3). As seen in Fig. 3, however, differences in Kratky plots for $\operatorname{LRAP}(+\mathrm{P})$ and $\operatorname{LRAP}(-\mathrm{P})$, which persist even in the presence of the highest calcium concentration studied at high $s$ values, suggest that $\operatorname{LRAP}(+\mathrm{P})$ remains somewhat more unfolded than $\operatorname{LRAP}(-\mathrm{P})$ under these conditions. Additional studies will be needed to provide insight into other potential differences in $\operatorname{LRAP}(+\mathrm{P})$ and LRAP $(-\mathrm{P})$ self-assembly, as briefly noted above.

The remarkable conformational difference between $\operatorname{LRAP}(+\mathrm{P})$ and $\operatorname{LRAP}(-\mathrm{P})$ shown here offers a possible explanation for the differences observed in assembly behavior and for the effects that these peptides have on calcium phosphate precipitation in vitro. Changes in the folding of $\operatorname{LRAP}(+\mathrm{P})$, induced by the addition of calcium, may result from favorable calcium interactions with specific peptide sites that are exposed in the less- folded LRAP $(+\mathrm{P})$ molecules. Such interactions lead to an enhancement of protein-protein interactions and to the formation of higher-order anisotropic chain-like structures (19). Hence, based on our present findings, it is concluded that the presence of the single phosphate group in LRAP induces functionally important conformational changes in the protein structure that favor the formation of higher-order protein assemblies. Accordingly, specific structure-changing calcium interactions that take place with $\operatorname{LRAP}(+\mathrm{P})$ do not occur with the non-phosphorylated $\operatorname{LRAP}(-\mathrm{P})$, as $\operatorname{LRAP}(-\mathrm{P})$ is inherently more tightly folded and key calcium-binding sites are concealed. Furthermore, observed differences in folding, and the tendency for $\operatorname{LRAP}(+\mathrm{P})$ to form less folded structures in the absence and presence of calcium, may also explain why phosphorylated $\operatorname{LRAP}(+\mathrm{P})$ is much more effective in stabilizing ACP nanoparticles and preventing the transformation of ACP into HA. The more open structure and the calcium-induced folding of $\operatorname{LRAP}(+\mathrm{P})$, in the presence of calcium and phosphate under mineralizing conditions, could lead to a more effective sequestration of forming ACP nanoparticles that prevents the transformation of ACP to HA. The fact that $\operatorname{LRAP}(-\mathrm{P})$ has been shown to stabilize ACP only transiently (19) is consistent with the present findings and this developing hypothesis on the effect of phosphorylation on protein conformation and mineralization. However, it is important to consider that previous findings also show that $\operatorname{LRAP}(-\mathrm{P})(19)$, like the full-length non-phosphorylated amelogenins rM179 (5) and rP172 (8), has the capacity to regulate the formation of ordered arrays of apatitic crystals by guiding the alignment, fusion, and subsequent transformation of the initially formed ACP nanoparticles (8). This capability 

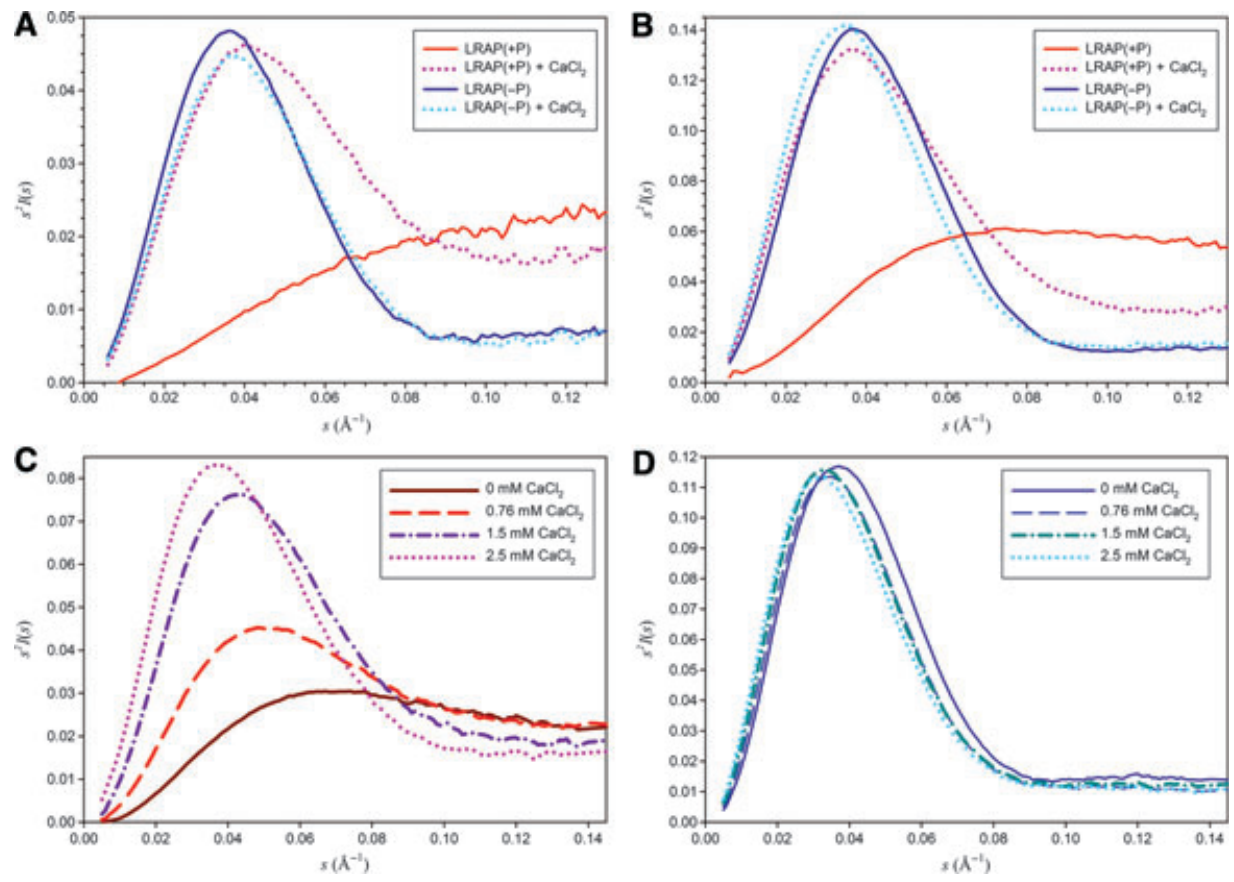

Fig. 3. Small angle X-ray scattering (SAXS) analyses of non-phosphorylated leucine-rich amelogenin peptide [LRAP(-P)] and phosphorylated leucine-rich amelogenin peptide $[\operatorname{LRAP}(+\mathrm{P})]$. Kratky plots of $\operatorname{LRAP}(-\mathrm{P})$ and $\operatorname{LRAP}(+\mathrm{P})$ at $2 \mathrm{mg} \mathrm{ml}^{-1}(\mathrm{~A})$ and $5 \mathrm{mg} \mathrm{ml}^{-1}$ (B-D) were determined in the absence and in the presence of $2.5 \mathrm{mM} \mathrm{CaCl}_{2}$ (A and B) and from 0 to $2.5 \mathrm{mM} \mathrm{CaCl}_{2}(\mathrm{C}$ and $\mathrm{D})$. The plots of LRAP $(-\mathrm{P})$ in the absence and presence of calcium showed a similar bell-shaped curve, indicating globular structures (A, B and D). However, in the absence of calcium (A and B), LRAP( + P) showed a plateau indicating an unfolded structure, whereas a prominent peak appeared upon the addition of $2.5 \mathrm{mM}$ calcium (A and B). This latter peak was found to become increasingly more pronounced as a function of calcium concentration $(\mathrm{C})$, suggesting the formation of a more globular LRAP $(+\mathrm{P})$ structure in the presence of added calcium. $I(s)$, intensity of $s ; s$, scattering vector.

was found to depend on the presence of the hydrophilic $\mathrm{C}$ terminus in both amelogenin and LRAP (20). Based on these collective findings, additional processes [e.g. proteolysis or dephosphorylation, as we have recently discussed (19)] may be involved in vivo to trigger the subsequent transformation of initially formed ACP particles, as found in the early stages of developing enamel (37). We propose that initially formed ACP mineral in developing enamel is stabilized by native phosphorylated amelogenins that guide the accumulation and linear arrangement of amorphous nanoparticles which serve as precursors to enamel crytallites.

In conclusion, we have shown that the single phosphate group in $\operatorname{LRAP}(+\mathrm{P})$ induces functionally important conformational changes, particularly with respect to calcium interactions. Although further studies are needed, the present findings suggest that phosphorylation may also influence amelogenin conformation and subsequent protein-mineral interactions during the early stages of amelogenesis.

Acknowledgement - This work was supported by grant DE016376 (to H.C.M) from the National Institute of Dental and Craniofacial Research. Use of beamline X9 and the National Synchrotron Light Source, Brookhaven National Laboratory, was supported by the US Department of Energy, Office of Science, Office of Basic Energy Sciences, under contract no. DE-AC02-98CH10886.

Conflicts of interest - The authors declare that there are no conflicts of interest with respect to this manuscript.

\section{References}

1. NANCI A. Enamel: composition, formation and structure. In: NANCI, ed. Ten Cate's oral histology - development, structure, and function, 7th edn. St Louis: Mosby Inc., 2008; 141190.

2. Aichmayer B, Margolis HC, Sigel R, Yamakoshi Y, Simmer JP, FRATZL P. The onset of amelogenin nanosphere aggregation studied by small-angle X-ray scattering and dynamic light scattering. J Struct Biol 2005; 151: 239-249.

3. Aichmayer B, Wiedemann-Bidlack FB, Gilow C, Simmer JP, Yamakoshi $\mathrm{Y}$, Emmerling $\mathrm{F}$, Margolis HC, Fratzl P. Amelogenin nanoparticles in suspension: deviations from spherical shape and $\mathrm{pH}$-dependent aggregation. Biomacromolecules 2010; 11: 369-376.

4. Fincham AG, Moradian-Oldak J, Diekwisch tGH, Lyaruu DM, Wright JT, Bringas JRP, SLAvkin HC. Evidence for amelogenin "nanospheres" as functional components of secretory-stage enamel matrix. J Struct Biol 1995; 115: 50-59.

5. Beniash E, Simmer JP, Margolis HC. The effect of recombinant mouse amelogenins on the formation and organization of hydroxyapatite crystals in vitro. $J$ Struct Biol 2005; 149: $182-190$

6. Wiedemann-Bidlack FB, Beniash E, Yamakoshi Y, Simmer JP, MARGOLIS HC. $\mathrm{pH}$ triggered self-assembly of native and recombinant amelogenins under physiological $\mathrm{pH}$ and temperature in vitro. $J$ Struct Biol 2007; 160: 57-69.

7. Wiedemann-Bidlack FB, Kwak SY, Beniash E, Yamakoshl Y, Simmer JP, Margolis HC. Effects of phosphorylation on the self-assembly of native full-length porcine amelogenin and its regulation of calcium phosphate formation in vitro. $J$ Struct Biol 2011; 173: 250-260.

8. Kwak Sy, Wiedemann-Bidlack FB, Beniash E, Yamakoshi Y, Simmer JP, Litman A, Margolis HC. Role of 20-kDa amelogenin (P148) phosphorylation in calcium phosphate formation in vitro. $J$ Biol Chem 2009; 284: 18972-18979. 
9. Margolis HC, Beniash E, Fowler CE. Role of macromolecular assembly of enamel matrix proteins in enamel formation. $J$ Dent Res 2006; 85: 775-793.

10. Moradian-Oldak J, Tan J, Fincham AG. Interaction of amelogenin with hydroxyapatite crystals: an adherence effect through amelogenin molecular self-association. Biopolymers 1998; 46: 225-238.

11. Tarasevich BJ, Howard CJ, Larson JL, Snead ML, Simmer JP, PAINE M, SHAW WJ. The nucleation and growth of calcium phosphate by amelogenin. J Cryst Growth 2007; 304: 407-415.

12. Wang L, Guan X, Du C, Moradian-Oldak J, Nancollas $\mathrm{GH}$. Amelogenin promotes the formation of elongated apatite microstructures in a controlled crystallization system. $J$ Phys Chem C nanomater interfaces 2007; 111: 6398-6404.

13. Paine ML, Snead ML. Protein interactions during assembly of the enamel organic extracellular matrix. J Bone Miner Res 1997; 12: 221-227.

14. Paine ML, Luo W, Zhu DH, Bringas JRP, Snead ML. Functional domains for amelogenin revealed by compound genetic defects. J Bone Miner Res 2003; 18: 466-472.

15. Paine ML, Wang HJ, Snead ML. Amelogenin self-assembly and the role of the proline located within the carboxyl-teleopeptide. Connect Tissue Res 2003; 44 (Suppl 1): 52-57.

16. Pugach MK, Li Y, Suggs C, Wright JT, Aragon MA, Yuan ZA, Simmons D, Kulkarni AB, Gibson CW. The amelogenin C-terminus is required for enamel development. $J$ Dent Res 2010; 89: 165-169.

17. Yamakoshi Y, Tanabe T, Oida S, Hu CC, Simmer JP, Fukae $\mathrm{M}$. Calcium binding of enamel proteins and their derivatives with emphasis on the calcium-binding domain of porcine sheathlin. Arch Oral Biol 2001; 46: 1005-1014.

18. Аовa T, Moreno EC. The enamel fluid in the early secretory stage of porcine amelogenesis: chemical composition and saturation with respect to enamel mineral. Calcif Tissue Int 1987; 41: 86-94.

19. Le Norcy E, Kwak Sy, Wiedemann-Bidlack FB, Beniash E, Yamakoshi Y, Simmer JP, Margolis HC. Leucine-rich amelogenin peptides regulate mineralization in vitro. $J$ Dent Res 2011; 90: 1091-1097.

20. Le Norcy E, Kwak Sy, Wiedemann-Bidlack FB, Beniash E, YAMAKoshi Y, Simmer JP, MARgolis HC. Potential role of the amelogenin $\mathrm{N}$-terminus in the regulation of calcium phosphate formation in vitro. Cells Tissues Organs 2011; 194: 188-193.

21. Habelitz S, Denbesten PK, Marshall SJ, Marshall GW, L W. Self-assembly and effect on crystal growth of the leucinerich amelogenin peptide. Eur J Oral Sci 2006; 114 (Suppl 1): 315-319.

22. TARASEvich BJ, Lea S, Shaw WJ. The leucine rich amelogenin protein (LRAP) adsorbs as monomers or dimers onto surfaces. J Struct Biol 2010; 169: 266-276.

23. Le TQ, Gochin M, Featherstone JD, Li W, Denbesten PK. Comparative calcium binding of leucine-rich amelogenin pep- tide and full-length amelogenin. Eur J Oral Sci 2006; 114 (Suppl 1): $320-326$.

24. Nagano T, Kakegawa A, Yamakoshi Y, Tsuchiya S, Hu JC, Gomi K, Arai T, Bartlett JD, Simmer JP. Mmp-20 and Klk4 cleavage site preferences for amelogenin sequences. J Dent Res 2009; 88: 823-828.

25. Allaire M, Yang L. Biomolecular solution X-ray scattering at the National Synchrotron Light Source. J Synchrotron Radiat 2011; 18: 41-44.

26. Konarev PV, Volkov VV, Sokolova AV, Koch MHJ, SVERGUN DI. PRIMUS: a Windows PC-based system for smallangle scattering data analysis. J Appl Cryst 2003; 36: 12771282 .

27. Guinier A, Fournet G. Small-angle scattering of X-rays. New York: Wiley, 1955.

28. Glatter O, Kratky O, eds. Small-angle X-ray scattering. London: Academic Press, 1982.

29. Kearney KR, Moore PB. X-ray solution-scattering studies of active and inactive Escherichia coli ribosomal subunits. $J \mathrm{Mol}$ Biol 1983; 170: 381-402.

30. Semisotnov GV, Kihara H, Kotova NV, Kimura K, Amemiya Y, Wakabayashi K, Serdyuk IN, Timchenko AA, Chiba K, Nikaido K, Ikura T, Kuwajima K. Protein globularization during folding. A study by synchrotron small-angle X-ray scattering. $J$ Mol Biol 1996; 262: 559-574.

31. Doniach S. Changes in biomolecular conformation seen by small angle X-ray scattering. Chem Rev 2001; 101: $1763-$ 1778.

32. Putnam CD, Hammel M, Hura GL, Tainer JA. X-ray solution scattering (SAXS) combined with crystallography and computation: defining accurate macromolecular structures, conformations and assemblies in solution. Q Rev Biophys 2007; 40: $191-285$

33. Fincham AG, Moradian-Oldak J, Sarte PE. Massspectrographic analysis of a porcine amelogenin identifies a single phosphorylated locus. Calcif Tissue Int 1994; 55: 398400 .

34. Buchko GW, Tarasevich BJ, Bekhazi J, Snead ML, Shaw WJ. A solution NMR investigation into the early events of amelogenin nanosphere self-assembly initiated with sodium chloride or calcium chloride. Biochemistry 2008; 47: 1321513222.

35. He X, Wu S, Martinez-Avila O, Cheng Y, Habelitz S. Selfaligning amelogenin nanoribbons in oil-water system. $J$ Struct Biol 2011; 174: 203-212.

36. Shaw WJ, Ferris K. Structure, orientation, and dynamics of the C-terminal hexapeptide of LRAP determined using solidstate NMR. J Phys Chem B 2008; 112: 16975-16981.

37. Beniash E, Metzler RA, Lam RSK, Gilbert PUPA. Transient amorphous calcium phosphate in forming enamel. $J$ Struct Biol 2009; 166: 133-143. 